
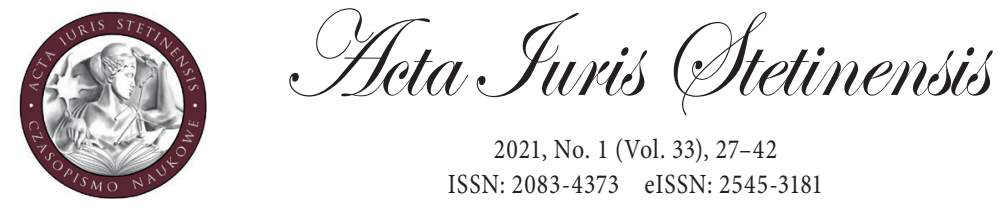

2021, No. 1 (Vol. 33), 27-42

ISSN: 2083-4373 eISSN: 2545-3181

DOI: 10.18276/ais.2021.33-02

Adam Drozdek

Ph.D., advocate, customs agent

Cracow University of Economics, Poland

College of Economy and Public Administration

OPEN ACCESS

Department of Regulatory Policies

e-mail: adam_drozdek@poczta.onet.pl

ORCID ID: 0000-0002-0942-3347

\title{
The taxpayer's claim under the tax law relationship of a tax overpayment
}

\begin{abstract}
The purpose of the research undertaken in this paper is to analyse the tax claim. It is an institution that has its source in a subjective right. As part of a tax claim, a taxable entity may assert its rights resulting from the obligation-involving tax law relationship of a tax overpayment. The institution of crediting overpayments towards tax arrears and current obligations is a special type of tax claims securing the exercise of the rights of taxable entities under the tax law relationship. The basic research method used for the purposes of the analysis undertaken in this publication is a comprehensive analysis of the normative status of the issues analysed and of selected views of legal commentators and of judicial and administrative decisions.
\end{abstract}

Keywords: tax claim, tax overpayment, taxpayer, tax 


\section{Introduction}

The creation of a tax law relationship of tax overpayment results in an obligation which is characteristic of an obligation-involving relationship. A special type of tax claims securing the exercise of rights of taxable entities under the tax law relationship is the institution of crediting overpayments to tax arrears and current obligations. It allows a requirement that a specific entity should behave in a specific way, which derives from a tax law standard. In this case, there is a situation in which a party obliged by the tax law relationship of a tax overpayment has rights to demand from the entitled party a certain behaviour which results in counting the overpayments towards tax arrears and current obligations of the taxpayer. These situations cause that the occurrence of a tax overpayment does not give the entitled party full freedom to dispose of it, as the legal standard defines a procedure for its reimbursement. It is also characteristic that the legislator has planned the way of dealing with the overpayment in advance, imposing a specific procedure on the obliged party. The recognition of a tax overpayment by an obliged party shall result in the initiation of a specific procedure, which leads to the right of the entitled party to receive reimbursement of the tax overpayment together with interest for this period only and exclusively in the absence of tax arrears and current obligations.

The purpose of this paper is to analyse the legal solutions concerning the rights and responsibilities of a taxpayer based on the example of counting the tax overpayment towards tax arrears and current obligations of the taxpayer. To this end, the provisions of the Tax Ordinance Act ${ }^{1}$ relating to the ways of disposing of tax overpayment under the tax law relationship of the tax overpayment will be discussed. The starting point will be to present the concept of a claim developed by legal scholars and commentators and to define its scope under tax law. In the following part, the definition, and the moment when the tax overpayment occurs will also be characterized.

\section{The essence of a tax claim}

The essence and legal nature of the "tax claim" has not been the subject of wider research by representatives of the science of tax law. Therefore, it seems necessary to use solutions developed in other areas of the law, especially private law.

1 Act of 29 August 1997 Tax Ordinance Act, consolidated text, Dz.U. (Journal of Laws) of 2020, item 1325, as amended, hereinafter: the Tax Ordinance Act. 
The theory of law adopts a definition of a claim formulated by S. Wronkowska as an entitlement under which one entity is individually entitled and the other one is obliged to the performance due. The said author also indicates that it is a material claim, which is a special entitlement in the form of reimbursement to the entitled person of the due performance of an obligation-involving nature. ${ }^{2}$ In the context of a claim, an individually designated person has a duty to deliver a performance for the person entitled, and the latter may demand that this person should behave in accordance with the legal norm, in a strictly defined manner. In this case, the entitlement has been specified in terms of content and of the entity concerned in the duty of another entity. ${ }^{3}$ This means that the claim pre-determines both the behaviour to which a certain entity is obliged and the entity itself, as obliged to perform a certain behaviour prescribed by legal standards. There is, therefore, a pre-determined addressee of the responsibilities, as well as his/her behaviour, which determines the rights of the party entitled due to the claim. Claims most often occur in contractual relations, which means that their classic form is a claim ${ }^{4}$ directed against an individually identified entity. ${ }^{5}$ In this respect, we should agree with W. Jakimowicz, who underlines that a claim is based on a subjective right. Its content is the possibility for the taxpayer to effectively claim by means of an individualised claim, strictly defined by the law in force, that a public-law entity should behave in a way that corresponds to the requestor's legal interest. This means that a claim should be understood as an instrument given to us by law that makes it possible to require that the state should behave strictly according to a subjective right. ${ }^{6}$

When transposing the above arguments into tax law, it should be assumed that the term "tax claim" should be understood as a type of entitlement derived from a substantive right, which consists in a right of the entitled person to demand from an individually designated entity a specific conduct consisting of an act or omission, while the scope of a specific behaviour of one entity determines at the same time the sphere of the other entity's ability to act. Thus, based on a tax claim, an entity obtains the right to claim reimbursement of an undue payment, which is defined in

2 S. Wronkowska, Sytuacje wyznaczone przez normy prawne, in: A. Redelbach, S. Wronkowska and Z. Ziembiński (eds.), Zarys teorii państwa i prawa, Warszawa 1993, p. 149.

3 A. Voltaire, Prawo cywilne. Zarys części ogólnej, Warszawa 1972, p. 115.

4 E. Gniewek, Podstawy prawa cywilnego, Warszawa 2010, p. 171.

5 J. Wiszniewski, Zarys prawa cywilnego, Warszawa 1969, p. 48.

6 W. Jakimowicz, Publiczne prawa podmiotowe, Kraków 2002, pp. 135, 218. 
an individual manner. ${ }^{7}$ An example of such a material claim is the reimbursement of overpaid or unduly paid tax. This leads to the conclusion that a subjective right is always a correlate of the tax authority's responsibility, that is to say its competence in the strict sense of this term. This means that the existence of a subjective right determines to the end the behaviour of the tax authority, which it cannot evade. ${ }^{8}$

There is a well-established view among tax law scholars that a "tax claim" arises regardless of the taxpayer's will. Such a view is presented, for example, in the literature of German law, where it is claimed that a tax claim arises by virtue of the law itself, once the tax law status of the tax norm becomes a reality. ${ }^{9}$ This means that the decision issued by tax authorities is purely declaratory. In turn, H. Dzwonkowski notes that a tax claim has its source in the obligation-involving relationship, which includes not only the tax obligation within the meaning of Polish tax law (property claims), but also the taxpayer's claim related to overpayment or tax refund (nonproperty claims). ${ }^{10}$

Therefore, in the light of the above, it must be concluded that the scope of the tax claim corresponds to the form of the claim made by the entitled party to the obliged party (public body). The content of a tax claim includes the power to require that the designated entity, in this case the tax authority, should behave in a certain manner, i.e., to fulfil its responsibilities, allowing the rights of the entitled party to be exercised, while at the same time providing a guarantee of proportionality in the payment of public levies. In the case of a tax claim, we are dealing with a reversal of the "classic" relationship between tax and law, where the public-law entity represented by a tax authority acts as the creditor and the taxpayer acts as the debtor. This relationship causes the public-law entity to become a debtor, while the taxpayer is a creditor entitled to demand a certain behaviour from the other party to the tax relationship. ${ }^{11}$ In these conditions, the statement that within the framework of a tax claim an important role is played by the right to demand a specific behaviour from

7 M. Popławski, Roszczenia podatkowe - specyfika i klasyfikacja, in: J. Głuchowski, A. Pomorska and J. Szolno-Koguc (eds.), Podatkowe i niepodatkowe źródła finansowania zadań publicznych, Lublin 2007, pp. 95-96.

8 Judgment of the Voivodship Administrative Court in Warszawa of 5 March 2013, III SA/Wa 2334/12, LEX No. 1321547.

9 H.W. Kruse, Lehrbuch des Steuerrechts, Bd. 1, Allgemeiner Teil, München 1991, pp. 119-120.

10 See H. Dzwonkowski, Powstanie i wymiar zobowiązań podatkowych, Warszawa 2003, pp. 36-38; similarly, private law scholars: A. Ohanowicz, Zobowiązania. Część ogólna, Poznań 1958, p. 17; A. Wolter, J. Ignatowicz, K. Stefaniak, Prawo cywilne. Zarys czę́ci ogólnej, Warszawa 2000, p. 125.

11 M. Popławski, Uprawnienia podatkowe. Procedura dochodzenia należności podatkowych od Skarbu Państwa lub jednostek samorzadu terytorialnego, Warszawa 2014, p. 61. 
an individually designated public entity which will secure the exercise of tax rights of taxable entities of a tax law relationship should not raise any doubts. The rights and entitlements arising from a tax claim, therefore, make it possible to protect the interest of the taxpayer, namely to ensure that the taxpayer has legal instruments at his/her disposal to precisely determine the extent of his/her rights and responsibilities under the provisions of substantive tax law.

\section{Definition and occurrence of tax overpayment}

The provisions of the Tax Ordinance Act in Article 72(1) define tax overpayment as a monetary amount of overpaid or unduly paid tax. The content of the abovementioned legal regulation suggests that tax overpayment consists of two types of performances of a different legal nature. On the one hand, it is a cash performance which has arisen as a result of a payment made by taxable entities of a tax law relationship, and therefore the payment made is justified by an existing tax liability or obligation. In this case, the tax overpayment is in a way related to the existing tax law relationship between the tax creditor and the taxpayer, in particular due to the tax liability and obligation. The tax overpayment understood in this way constitutes a tax overpayment sensu stricto. The second type of performances, on the other hand, are those paid unduly and arising where a certain entity has paid a certain amount of money to the tax authority without being obliged to do so at all or being obliged to pay a lower amount. In this case, the entity paying the performance has no tax liability or this liability has not yet converted into a tax obligation. Therefore, there is no link resulting from the tax law relationship between the tax authority and the entity paying the performance. The entity, when making the payment of such a performance, remains in the mistaken belief of the obligation imposed on it. Undue performance also exists where there was a legal basis for the performance at the time it was paid, but that basis ceased to exist afterwards, for example because the decision had been annulled or declared invalid. The type of tax overpayment presented constitutes a tax overpayment sensu largo. ${ }^{12}$

When examining the provisions of the Tax Ordinance Act regarding overpayment, it should be noted that the concept of overpayment also applies to other performances, to which the legislator, for example, also included unduly paid

12 Z. Ofiarski, Ogólne prawo podatkowe. Zagadnienia materialnoprawne i proceduralne, Warszawa 2010, pp. 173-174. 
arrears, default interest on tax arrears and a prolongation fee. ${ }^{13}$ In this way, overpayment of tax is understood as not only prepayment of personal and corporate income tax, tax instalments with interest or a prolongation fee, but also other nontax cash performances, which include budget fees and non-tax receivables.

M. Kalinowski presents an important view on the issue in question, drawing attention to the fact that the legislator's use of the terms "taxpayer" and "tax" to define an overpayment should be treated conventionally ${ }^{14}$ as an undue performance, but performed against the backdrop of a universally understood tax law relationship, with an erroneous belief of the fulfilment of a tax obligation and with reference to tax law grounds for such action contained in tax regulations. ${ }^{15} \mathrm{~A}$ contrario, it must be therefore assumed that what is defined in the provisions of the Tax Ordinance Act as tax overpayment does not fall within the concept of tax obligation and is therefore not a tax. The term "tax" has been defined in Article 6 of the Tax Ordinance Act, according to which it is a free-of-charge, compulsory, public and legal, non-refundable and financial performance, resulting from the tax act, paid to the State budget or a local government unit. Given the above, a conclusion arises that the tax cannot be paid unduly, because in this case such a performance is losing its "tax" status. The use by the legislator of the term "tax" and "taxpayer" in the definition of tax overpayment is intended to distinguish overpayment as a tax law performance from private and legal performances ${ }^{16}$ referred to in Article 410 of the Tax Ordinance Act. ${ }^{17}$ This means that performances which are not of a public and legal nature cannot be granted the status of tax overpayment, as the amount of such a performance has no legal basis in the provisions of the law in force. Such a view had also gained approval in the body of judicial decisions before the Tax Ordinance Act entered into force. For example, in its resolution of 21 March 1996, III AZP 39/95, the Supreme Court took the position that an overpayment should not be equated with a tax obligation, and that consequently, an overpayment is not a tax. In the court's opinion, it constitutes an undue financial performance of

13 See Article 72(2) of the Tax Ordinance Act.

14 M. Kalinowski, Nadpłata w świetle przepisów Ordynacji podatkowej, in: Z. Chmiel (ed.), Księga pamiątkowa ku czci Docenta Eligiusza Drgasa, Toruń 1998, p. 84.

15 H. Dzwonkowski, Nadpłata, in: H. Dzwonkowski (ed.), Ordynacja podatkowa. Komentarz, Warszawa 2013, p. 486.

16 J. Zubrzycki, Nadpłata, in: B. Adamiak, J. Borkowski, R. Mastalski and J. Zubrzycki (eds.), Ordynacja podatkowa. Komentarz, Wrocław 2005, p. 344.

17 Act of 23 April 1964 on the Civil Code, consolidated text: Dz.U. (Journal of Laws) of 2020, item 1740 , as amended. 
a private and legal nature, which the taxpayer was not obliged to fulfil (undue performance). In the reasons for this view, the Supreme Court referred, for example, to the fact that the tax overpayment cannot be treated as the fulfilment of a tax obligation as a public law obligation or a personal performance strictly related to the taxable entity. Making a tax overpayment as a result of a mistake made by a taxpayer cannot be counted as fulfilling a tax performance as it goes beyond the liability under tax law. Therefore, by its very nature, an overpayment is not a legal tax obligation, as tax liability means an obligation to pay the tax. It has the nature of a complex tax law relationship, which involves the imposition of a number of substantive and procedural responsibilities on the taxpayer, in particular submission to tax proceedings leading to individualised tax liability. Tax liability means the taxpayer's responsibility to bear the tax burden to the extent specified in the Act in the event of an occurrence of the facts that correspond to the hypothesis of a tax norm. It mainly includes the responsibility to pay a cash performance to the state as well as other specific obligations related thereto, which make it possible to fulfil this liability, such as reporting the occurrence of specific facts covered by a tax norm to the tax authority, submitting a tax return or tax statements. ${ }^{18}$

Without entering into a detailed discussion of the problem signalled, as this would go beyond the thematic framework of this paper, it should be considered that the essence of the tax overpayment lies not only in the taxable tax law relationship, but also in the actions of the taxing party of the tax law relationship or of persons representing the tax authority. Undoubtedly, the distinguishing feature of an overpayment is that the taxable party of the tax law relationship or its participant makes a cash payment to the account of a competent tax authority in an amount exceeding the tax obligation or in an undue amount, or as a result of a constitutive or declaratory decision issued by a tax authority, which later is revoked or removed from legal transactions. The concept of overpaid tax should be applied to such situations where the basis for payment of the tax existed, i.e. based on the existing tax relationship, but the taxpayer who was wrong, paid a higher amount than it resulted from the tax liability, or the amount of paid tax was correct, but as a result of the actions of an entity representing the State Treasury (tax creditor), the basis for payment of the tax ceased to exist (annulment or removal of a constitutive or declaratory decision). On the other hand, the concept of undue tax should be understood as a situation in which the overpayment occurred as

18 LEX No. 24977; see also: P. Pogonowski, Charakter prawny nadpłaty podatkowej, "Przegląd Legislacyjny" 2004, No. 3, Vol. 43, p. 77. 
a result of the payment of a performance without a legal basis, i.e., when there were no substantive law provisions which would oblige the entity to pay such tax. When a tax overpayment occurs, the basic legal relationship between the taxpayer (tax debtor) and the tax authority (tax creditor) expires because the taxpayer settles the tax debt required by law and a tax law relationship of overpayment occurs, in which the roles of the entities are reversed.

Against the background of the legal arguments presented, it should be noted that in most cases the tax law relationship of tax overpayment arises already on the date of payment by the taxpayer of undue tax or in an amount higher than due, or on the date of its collection by the tax remitter in such an amount. ${ }^{19}$ The relevant literature indicates that the date of payment of undue tax or in the amount higher than due will be the moment when the tax law relationship of overpayment arises in the case of payment of a liability arising from a tax liability decision, if in such decision the tax liability was unduly determined or in the amount higher than due. In this respect, the provisions of the Tax Ordinance Act provide for identical treatment of tax remitters, collectors, third parties and heirs who have made payments based on tax liability decisions. Therefore, the rule relating to the moment when the tax law overpayment relationship arises covers situations where the remitter or collector makes a tax payment in excess of the tax collected from the taxpayer. The provisions of the Tax Ordinance Act provide also for circumstances in which the tax law relationship of tax overpayment arises later than at the time of payment of the undue or overpaid amounts. In this case, the tax law relationship of tax overpayment arises not on the date of payment of the tax, but only on the date on which the tax authority is informed of its existence by submitting a tax statement or return. ${ }^{20}$ Examples of such situations include the submission of:

- an annual personal and corporate income tax statement,

- $\quad$ an excise duty return, and

- a declaration on payments from the profit for a given accounting year for sole shareholder State Treasury companies and state enterprises. ${ }^{21}$

19 See Article 73(1) of the Tax Ordinance Act.

20 M. Ignasiak, Nadpłata podatku - tryb i termin jej zwrotu, "Przegląd Podatkowy" 2006, No. 5, p. 42; A. Drozdek, Stosunki podatkowo-prawne w nadplacie podatków, Toruń 2020, p. 262.

21 See Article 73(2) of the Tax Ordinance Act. 


\section{Crediting the claimed tax overpayment for outstanding and current tax obligations}

The regulations in the valid Tax Ordinance Act provide that within the framework of the tax law relationship of a tax overpayment, the overpayment shall be credited first to outstanding and current tax obligations. Outstanding tax obligations are those which have not been fulfilled by the taxpayer within the deadline set by the legal norm. In the case of outstanding tax obligations, it is irrelevant whether the tax was not paid through the fault of the taxpayer or as a result of other circumstances beyond the will of the parties to the tax law relationship. This means that the mere fact of not paying tax, regardless of the circumstances, lying on the part of any party to a tax law obligation relationship, results in tax arrears. It arises by virtue of the law on the day following the day on which the deadline for payment specified by the tax law norm expired. The provisions of the tax law consider tax arrears to be prepayments of tax or tax instalments not done on time. Current obligations, on the other hand, should be understood as obligations which have already arisen, their actual state of affairs or period of their occurrence has been closed, but the payment deadline has not yet passed. ${ }^{22}$ Therefore, current obligations are those relating to pre-payments of personal and corporate income tax and instalments resulting from the construction of the tax even though their payment deadline has not yet expired. ${ }^{23}$ In view of the above, it should be stated that "tax obligations" and "current obligations" may include existing obligations resulting from the tax law relationship of tax overpayment and the tax law relationship due to the finding of a tax overpayment.

As it has already been indicated earlier, one of the ways entities may act on account of the tax claim under the tax law relationship of a tax overpayment is set out in Article 76(1) of the Tax Ordinance Act. This legal provision imposes responsibility on the party obliged by virtue of the overpayment to maintain a certain regime of conduct with the overpayment. A party obliged by virtue of a tax overpayment is first of all obliged, pursuant to a legal standard, to include, ex officio, the overpayment together with interest, on account of overdue and current tax obligations of the party entitled by virtue of the tax overpayment, together with default interest, default interest on unpaid prepayment of tax, reminder costs and current

22 Judgment of the Voivodship Administrative Court in Gdańsk of 21 May 2014, I SA/Gd 174/14, LEX No. 1469659.

23 Judgment of the Supreme Administrative Court of 25 October 2016, II FSK 2807/14, LEX No. 2168501. 
tax obligations. Only in the second place, in the absence of overdue and current tax obligations, the overpayment can be returned ex officio. A party entitled to receive a tax overpayment may also apply for the overpayment in whole or in part to be credited towards future tax obligations. The regulation examined imposes the execution of an obligation arising from the overpayment on the parties to this relationship, that is correct settlement of the tax. This, in turn, involves the clarification for each of the parties of their rights and responsibilities that have their source in the tax law standard. The wording of the said legal regulation shows a specific sequence of events and stipulates that counting the tax overpayment towards future tax obligations is a modification of the obligation due to the tax overpaid. This modification can only take place if such obligation exists. ${ }^{24}$ These rules shall also apply mutatis mutandis to persons who are or were partners in a civil law partnership at the time of its termination. In this case, crediting the tax overpayment to tax arrears and current obligations requires the consent of all partners. However, this regulation applies only in the case of tax overpayments where the civil law partnership acts as a taxpayer and not as a partner, e.g., in value added tax and excise duty. It also follows from the literal wording of Article 76(1) of the Tax Ordinance Act that the tax overpayment should also be credited to heirs and third parties.

The above rules also apply to the reimbursement of tax overpayments to remitters and collectors in connection with their responsibilities under tax law. ${ }^{25}$ In practice, this means that the remitter's and collector's tax overpayments may be credited against their tax arrears together with interest, current tax obligations and those arising in connection with the performance of the remitter's or collector's responsibilities. In addition, from the point of view of the taxpayer, the obligation to credit the tax overpayment is an expression of the principle of certainty that the funds available to the taxpayer by virtue of the tax overpayment will be credited towards his/her tax obligations together with interest. This applies primarily to situations where the remitter or collector has an overpayment and at the same time has tax arrears as a taxpayer. This means that entities who become debtors enter into a legal obligation in place of the taxpayer. ${ }^{26}$ The aim of the above regulation is therefore to facilitate the extinction of the remitter's or collector's obligations in

24 See M. Ślifirczyk, Zaliczenie nadpłaty i zwrotu podatku jako przedmiot rozstrzygnięć organów podatkowych, in: R. Dowgier (ed.), Ordynacja podatkowa w praktyce. Rozstrzygnięcia organów podatkowych i skarbowych, Białystok 2014, pp. 269-283.

25 See Article 76(3)(1) of the Tax Ordinance Act.

26 R. Mastalski, Zobowiazania podatkowe, in: B. Adamiak, J. Borkowski, P. Borszowski, R. Mastalski and J. Zubrzycki (eds.), Ordynacja podatkowa. Komentarz, Wrocław 2017, p. 405. 
a situation where they have an overpayment and have parallel tax arrears as taxpayer or remitter (collector). The provision of Article 76(3) of the Tax Ordinance Act also provides for the possibility of counting the tax overpayment of the remitter or collector towards their future tax obligations. Within the framework of a tax law relationship of a tax overpayment, such a credit may be made not only ex officio by the party obliged by virtue of the tax overpayment, but also at the request of the party entitled by virtue of the tax overpayment. ${ }^{27}$ As a result of the inclusion of the tax overpayment on account of tax arrears and current tax obligations, a mutual deduction of receivables of the entitled party, on account of the tax overpayment (taxpayer), on account of the tax overpayment obligation, as well as receivables of a public-law association (party obliged on account of the tax overpayment) on account of the tax obligation is made. ${ }^{28}$ This view is confirmed by the legal regulation contained in Article 59(1)(1) and (3) of the Tax Ordinance Act, according to which the tax obligation expires in whole or in part by payment or deduction. As a result, it should be considered that an indirect refund has the features of statutory offsetting, which means that, in fact, an overpayment is a tax law deduction in favour of the taxpayer's obligations. This makes it possible to establish that, as soon as the overpayment is credited, the tax law relationship of overpayment will expire.

Summa summarum, Article 76 of the Tax Ordinance Act introduces a restriction on the entitled party's freedom to dispose of the amount of overpaid or unduly paid tax, and thus prevents such entity from freely disposing of the amount of overpaid or unduly paid tax and from using it for any purpose. The tax overpayment may be refunded only if the party entitled to the tax overpayment is not burdened with overdue obligations together with default interest and has no current obligations either. This view is based on the content of Article 76(1) of the Tax Ordinance Act, in which the legislator used the wording: "tax overpayments and their interest shall be credited ex officio". The application of this phrase by the legislator results in the fact that the credit of the tax overpayment within the framework of the tax law relationship is not dependent on the free discretion of the party obliged by virtue of the tax overpayment or on the disposition of the party entitled by virtue of the tax overpayment. The latter is allowed to dispose of the amount of the tax overpayment only with regard to future tax obligations. If the entitled party submits such a request, the party obliged by virtue of the tax overpayment is bound by it, which

27 See M. Popławski, Nadpłata i zwrot podatku. Zagadnienia wspólne dotyczace relacji uprawnień podatkowych, Warszawa 2014, p. 91.

28 M. Ślifirczyk, Potrącenie jako forma zapłaty podatku w polskim prawie podatkowym, Warszawa 1999, p. 27. 
at the same time means that it must execute this request. In this case, the right of the entitled party shall not limit either the order or the date of payment of future tax obligations. It should therefore be assumed that, as a result of an application being submitted by an entitled party in respect of a tax overpayment, it is released from the responsibility to pay tax, which will be covered from this overpayment. At the same time, it should be noted that in the event that a party entitled on account of a tax overpayment will not indicate the obligations to which it wants to transfer the amount of the tax overpayment, the party obliged on account of the tax overpayment should collect a relevant statement from it. The introduction of such a solution results in the fact that the party obliged by virtue of the tax overpayment cannot independently decide to which tax obligations the overpayment should be credited. ${ }^{29}$ The condition of being bound involves the existence of a future obligation at the date of the application. It is important that the party obliged by virtue of a tax overpayment should verify the status of overdue and current obligations before refunding the tax overdue. This, in turn, makes the eligible view that in case of their existence the obliged party is entitled - on the basis of a legal norm - to include the tax overpayment on account of these liabilities. ${ }^{30}$

When analysing the issue in question, it should also be noted that the provisions of the Tax Ordinance Act provide for the possibility of charging tax overpayment against tax arrears in the following cases: ${ }^{31}$

- on the date of payment by the taxpayer of undue tax or in an amount greater than that due,

- on the date on which the taxpayer is charged undue tax or in an amount greater than that due,

- on the date of payment by the remitter or collector of a due amount if such amount has been unduly determined or in an amount greater than that due,

- on the date of payment by a third party or heir of a receivable resulting from a tax liability decision or a decision determining the amount of the testator's tax obligation, if the receivable was unduly determined or in an amount greater than that due,

- on the date of submission of the annual tax statement in the case of income taxes,

29 O. Łunarski, Zapłata podatku, Gdańsk 2002, p. 184.

30 See M. Ślifirczyk, Charakter prawny wniosku o zaliczenie nadpłaty na poczet przyszłych zobowiazań podatkowych, in: R. Dowgier (ed.), Ordynacja podatkowa: kontrola realizacji zobowiąań podatkowych, Białystok 2012, p. 446.

31 See Article 76a(2) of the Tax Ordinance Act. 
- on the date of submission of the excise duty statement,

- on the date of submission of the declaration on payments from profit for the accounting year by sole shareholder State Treasury companies and state enterprises,

- on the date on which the application for recognition of the overpayment was submitted.

If a party entitled by virtue of a tax overpayment is burdened with obligations under several titles, the party obliged by virtue of the tax overpayment is entitled pursuant to the provisions of the tax law to credit the tax overpayment against the tax with the earliest payment date, unless the entitled entity makes use of its right to indicate to which tax the overpayment is to be credited. The rules established for the disposal of overpaid tax are applicable respectively to tax refund, i.e., the refund of tax difference or the refund of input tax within the meaning of the regulations on value added tax, excise tax, civil law transactions and stamp duty. In the case of submitting an application to declare a tax overpayment, such overpayment shall be credited against the tax arrears on the date of submitting this application. This means that the tax overpayment under the tax law relationship is credited against tax arrears not on the date on which the decision to credit is issued, but on the date on which the tax law relationship of the tax overpayment or the tax law relationship due to the finding of a tax overpayment is established. ${ }^{32}$

In conclusion, it should be stated that the responsibility of the entity liable on account of tax overpayment, resulting from the tax law standard, involves the proper settlement of the performance resulting from the tax overpayment. Inclusion of a tax overpayment on account of tax arrears and current obligations is a responsibility of the obliged party. As a consequence, the tax overpayment should be credited on the earliest possible date. In view of the possibility for an eligible entity to submit an application, it could be concluded that such application is not fully binding on the obliged party. In the event of the existence of tax arrears, default interest or current tax obligations, priority is given to the so-called indirect refund, i.e., the crediting of the tax overpayment against the overdue or current tax obligations. The legislator has unequivocally indicated that tax overpayment is independent of its occurrence and determination, as it imposes a responsibility on the party obliged by virtue of the tax overpayment to follow a certain sequence of proceedings. Within the framework of the tax law relationship, an obligation to take certain actions ex officio has

32 Judgment of the Voivodship Administrative Court in Gliwice of 14 May 2019, I SA/Gl 1264/18, LEX No. 2676440. 
been imposed, which in effect lead to the expiry of the tax law relationship of tax overpayment. Thus, the entitled entity has been deprived of the possibility to fully dispose of the tax overpayment. A contrario, the conclusion must be drawn that the absence of the tax arrears at the time when the tax overpayment occurs makes it impossible to count such overpayment towards arrears as, from the point of view of the tax law relationship, they do not exist. A party obliged by virtue of a tax overpayment cannot "wait" for the tax arrears to arise, and its responsibility, resulting from the provisions of the tax law, is to return ex officio the amount of overpaid tax to the entity entitled by virtue of a tax overpayment. Based on the application submitted, the authority shall credit the overpayment against future obligations. Moreover, it should be noted that it is important for the effective recognition of the overpayment that the tax arrears on which the overpayment is to be credited exist and are not time-barred. It is only when the overpayment has been credited that the tax obligation expires.

\section{Conclusions}

The analysis carried out as part of this paper leads to the following conclusions.

A tax claim is an institution associated with a tax law relationship. Its legal structure is determined by such elements as the entity (entitled and obliged) and the subject matter and content (which consists of the rights and responsibilities of the parties). Within the framework of the obligation-involving relationship, the entitled entity has the right to demand from the obliged party a certain behaviour which does not always consist in the transfer of funds. A tax claim allows the taxpayer to effectively demand a strictly defined behaviour, consistent with the content of tax law, from a specific entity under the tax law relationship. A contrario, this means that under no circumstances can a tax claim be based on a decision issued by a tax authority. The provisions of tax law bind not only the taxable party in the tax law relationship, but also the taxing party. Pursuant to the provisions of substantive tax law, the taxable party acquires substantive rights, for the protection of which it receives a number of means, e.g., to have the overpaid tax refunded.

A characteristic feature of the treatment of any tax overpayment that arises is such overpayment should in any case be set off against overdue and current tax obligations. This is provided for by the public law method of regulation. The content of the tax law relationship of tax overpayment is determined by the applicable tax law standards, and thus the obliged party is required to comply with the provisions of the tax law. In the case analysed, the unequal position of the entities means 
that the tax authorities are in charge of resolving the matters of the subordinate entity, i.e., the entity entitled to a tax overpayment.

\section{References}

Drozdek A., Stosunki podatkowo-prawne w nadplacie podatków, Torun 2020.

Dzwonkowski H., Nadpłata, in: H. Dzwonkowski (ed.), Ordynacja podatkowa. Komentarz, Warszawa 2013.

Dzwonkowski H., Powstanie i wymiar zobowiazań podatkowych, Warszawa 2003.

Gniewek E., Podstawy prawa cywilnego, Warszawa 2010.

Ignasiak M., Nadpłata podatku - tryb i termin jej zwrotu, "Przegląd Podatkowy" 2006, No. 5.

Kalinowski M., Nadpłata w świetle przepisów Ordynacji podatkowej, in: Z. Chmiel (ed.), Księga pamiątkowa ku czci Docenta Eligiusza Drgasa, Torun 1998.

Kruse H.W., Lehrbuch des Steuerrechts, Bd. 1, Allgemeiner Teil, München 1991.

Łunarski O., Zapłata podatku, Gdańsk 2002.

Mastalski R., Zobowiazania podatkowe, in: B. Adamiak, J. Borkowski, P. Borszowski, R. Mastalski and J. Zubrzycki (eds.), Ordynacja podatkowa. Komentarz, Wrocław 2017.

Ofiarski Z., Ogólne prawo podatkowe. Zagadnienia materialnoprawne i proceduralne, Warszawa 2010.

Ohanowicz A., Zobowiązania. Część ogólna, Poznań 1958.

Pogonowski P., Charakter prawny nadplaty podatkowej, "Przegląd Legislacyjny" 2004, No. 3, Vol. 43.

Popławski M., Roszczenia podatkowe - specyfika i klasyfikacja, in: J. Głuchowski, A. Pomorska and J. Szolno-Koguc (eds.), Podatkowe i niepodatkowe źródła finansowania zadań publicznych, Lublin 2007.

Popławski M., Uprawnienia podatkowe. Procedura dochodzenia należności podatkowych od Skarbu Państwa lub jednostek samorządu terytorialnego, Warszawa 2014.

Popławski M., Nadpłata i zwrot podatku. Zagadnienia wspólne dotyczace relacji uprawnień podatkowych, Warszawa 2014.

Ślifirczyk M., Potracenie jako forma zapłaty podatku w polskim prawie podatkowym, Warszawa 1999.

Ślifirczyk M., Charakter prawny wniosku o zaliczenie nadpłaty na poczet przyszłych zobowiazań podatkowych, in: R. Dowgier (ed.), Ordynacja podatkowa: kontrola realizacji zobowiazań podatkowych, Białystok 2012.

Ślifirczyk M., Zaliczenie nadpłaty $i$ zwrotu podatku jako przedmiot rozstrzygnięć organów podatkowych, in: R. Dowgier (ed.), Ordynacja podatkowa w praktyce. Rozstrzygnięcia organów podatkowych i skarbowych, Białystok 2014. 
Wiszniewski J., Zarys prawa cywilnego, Warszawa 1969.

Wolter A., Ignatowicz J., Stefaniak K., Prawo cywilne. Zarys części ogólnej, Warszawa 2000.

Wolter A., Prawo cywilne. Zarys części ogólnej, Warszawa 1972.

Wronkowska S., Sytuacje wyznaczone przez normy prawne, in: A. Redelbach, S. Wronkowska, Z. Ziembiński (ed.), Zarys teorii państwa i prawa, Warszawa 1993.

Zubrzycki J., Nadpłata, in: B. Adamiak, J. Borkowski, R. Mastalski and J. Zubrzycki (eds.), Ordynacja podatkowa. Komentarz, Wrocław 2005.

\section{CITATION}

Drozdek A., The taxpayer's claim under the tax law relationship of a tax overpayment, "Acta Iuris Stetinensis" 2021, No. 1 (Vol. 33), 27-42, 10.18276/ais.2021.33-02. 